\title{
Reviews
}

\begin{abstract}
Alister McGrath, Through a Glass Darkly: Journeys through Science, Faith and Doubt $-A$ Memoir (London: Hodder \& Stoughton 2021), pp. viii + 225, ISBN: 978-1529327625. £9.99
\end{abstract}

For many years Alister McGrath has published academic volumes, articles, and popular undergraduate textbooks on theology. In the latter part of his career, McGrath's academic publications have focused on the relationship between Christian theism and science, and although science features again in his latest work, Through a Glass Darkly is something rather different.

In this memoir McGrath shines a light on his own life and sits his audience down for a personal story which is full of intellectual depth, but also with personal and emotional investment. The book is structured in three major episodes: the first handles McGrath's growing zeal for atheism, the second his crisis of faith and eventual conversion to Christianity, and the third is a more philosophical reflection on the reasons for faith. Although this story is very much McGrath's own, it offers a particularly valuable perspective as a widely relatable memoir of the life of the mind. The power of memoir is the ability for the audience to see their own lives through someone else's eyes. I would wager many academics and theologians, especially those John Polkinghorne has called the 'scientist-theologians', will read some of their own life in the story before them. ${ }^{1}$ This is a story we share. It is a story of intellectual conversation, a personal reflection on what one used to believe and a record of a changed mind. I think this memoir will help its audience to gain confidence in not knowing. McGrath grows up, grows wiser, and grows less sure. In so doing he assures us that it is not an intellectual faux pas to cast our lot with the mystics.

McGrath was born among 'the soft low hills of Down' (p. 5, quoting C. S. Lewis) in the North of Ireland, a countryside that has inspired many

${ }^{1}$ John C. Polkinghorne, Science and the Trinity: The Christian Encounter with Reality (New Haven: Yale University Press, 2004), 60-64. 
a poet with its beauty. It inspired the young McGrath with a wonder and passion that led him to the natural sciences to better understand the beauty around him. He also mentions his initial introduction to Christianity. He was baptized as a child of a family that practised their faith nominally, if at all. His early engagement with Christianity is emblematic of the sort of implicit, loosely-defined breed of faith that has come to characterise so much of his generation's relationship to Christianity. Here the reader may already find a moment to reflect on their own lives. This kind of implicit Church of Ireland (read England or Scotland as well) Christianity is not an option that has been left open to upcoming generations. It is an endangered breed.

As McGrath grew up, he began seriously engaging with the life of the mind and the natural sciences. 'A good theory', he states, 'enables us to see the coherence of reality, disclosing (not inventing) a fundamental interconnection of things which might otherwise be overlooked' (p. 16). McGrath notes that at this time he was increasingly pulled between a meaningless but ordered world described by science and the liminal experiences of everyday life. The power of the way we experience the world has moved many to acknowledge that there may just be more to the material world than the cells and atoms of which it is composed. This calls to mind Lewis's argument from desire. If I find within myself a desire for something this world cannot satisfy, the only explanation is that I was made for another world. Simply put, one should not discount our experience of the world as both matter and spirit.

In his personal history, McGrath moves to Methodist College, a private academically rigorous boarding school near Queen's University Belfast. This school offered McGrath the resources required to become a talented and well-rounded intellectual. It also offered him the cultural viewpoint and academic resources to move from a scientifically motivated areligiosity to outright hostility. There are two major culprits for McGrath's transition to a more zealous form of atheism: Bertrand Russell and the Troubles. McGrath became convinced that, 'the advance of science thus required the suppression, or at least the cultural marginalisation, of religion. I shared his [Russell's] indignation, and began to think in terms of the warfare of science and religion - a war from which I trusted science would emerge as victor' (pp. 24-25). McGrath does not spend very much time on the Troubles, which he suggests bear some blame for his antireligiosity. Ultimately, he concludes that the conflict was mostly a product 
of cultural upheaval and political unrest with little religious concern involved: "Although widely presented as fundamentally religious in motivation, "the Troubles" were actually a political and ethnic conflict, reflecting two quite distinct sets of working-class beliefs and values' (p. 25).

At this point in his story, McGrath could have done more to address some of the deeper longings and divisive issues with which intellectually engaged people must contend. The Troubles are emblematic of the problem of suffering and the problem of ecclesiastical disappointment. It could well be that for McGrath the Troubles were not particularly religious. But might the experience of someone else in Ireland be very different? McGrath does not mention the very particular role he was playing in this context. McGrath was a young man, from a fairly wealthy family, private school-educated and Protestant. There is nothing wrong with any of these identifiers, but they mean he had a particular view onto the socio-political scene before him. Would an older, poorer, less-educated Catholic have the same experience of the Troubles? Maybe not. One can certainly debate to what extent many so called 'religious conflicts' are actually religious, but there are accounts of the Troubles, the Crusades, and other territorial wars suggesting very clearly that the people who were involved in them believed the conflicts were indeed about their religion. ${ }^{2}$

At this point in McGrath's personal story, he discovers scholars opposed to his own views. He finds books written by philosophers of science such as Karl Popper, and realizes that if Popper was right then the strident young atheist would need to come to terms with the 'awkward reality that all scientific knowledge is provisional, conjectural and hypothetical' (p. 43). Amid this crisis of faith, McGrath began his studies in chemistry at Oxford University. His friends, most of whom were natural sciences students, had religious views ranging from committed atheism to principled agnosticism to several different forms of Christianity. McGrath found that the natural sciences need not restrict thought about the nature of reality. With positivism behind him he began to look for something allencompassing; a theory of everything (and not just in the cosmological

\footnotetext{
${ }^{2}$ See Eamon Collins with Mick McGovern, Killing Rage (London: Granta Books, 1997) for a recollection of the Troubles as a religious conflict; Rodney Stark, God's Battalions: The Case for the Crusades (New York: HarperCollins, 2009) for a religious justification of the Crusades.
}

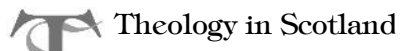


sense). As he looked for a theory that would fit this bill, he also found that the implicit cultural Christianity he had rejected was not Christianity at all. Indeed, he found that Christianity is about the Incarnation. This word, he began to grasp, 'expressed the core belief that Jesus Christ embodies God. God is with us - not merely in the sense of being on our side but also in the sense of standing alongside us, sharing our story and journeying with us' (p. 55). McGrath's academic career continued as he pursued a DPhil in molecular biophysics while attending additional tutorials in theology. McGrath's theological interests led him to further researches in theology at Cambridge University. After finishing his theological studies in Cambridge with the same level of intellectual skill he had shown studying chemistry at Oxford, McGrath moved on to the next phase of his life, ordination.

McGrath's life led him to public ministry in the Church of England. While serving as a curate in Nottingham, McGrath began to see clearly the importance of Christian living in thinking about academic Christian theology. He says, 'my time in Nottingham taught me that purely academic theology was inconceivable; all the great theologians of the Church had been pastors and preachers, and I resolved to follow in their footsteps' ( $p$. 110). McGrath's appointment in his church was coming to its end, leaving him wondering what he would do next. Then he stumbled upon a job opening at Wycliffe Hall back in Oxford. He jumped at the opportunity, secured the position, and moved his young family back to the city of dreaming spires. McGrath continued to hold various academic positions and published a bestselling response to Richard Dawkins's The God Delusion (though by no means his first critical response to the evolutionary biologist and Oxford colleague). These publications represent a significant portion of McGrath's career as a public intellectual. In addition to his written critique, he has also debated Dawkins multiple times. As such, McGrath has become one of the most prominent figures in the debate with the 'New Atheists'. In April 2014 he accepted a position as the Andreas Idreos Professor of Science and Religion and Director of the Ian Ramsey Centre for Science and Religion. Here McGrath brings together career, vocation, and conversion as part of his ultimate journey to become comfortable with the limits of his understanding; to admit what he does not know. He states, 'looking back, I now see holding the Oxford Idreos Professorship in Science and Religion as the culmination of my journey of

\section{Theology in Scotland}


discovery that I mapped out on the deck of a ferry crossing the Irish Sea on a winter night in December 1971. Yet I never could have predicted that the journey would take this particular form' (p. 132).

Now that McGrath has given his reader the long and engaging tale of his conversion, vocation, and ultimate destination, he returns to a few more philosophical points about the reasons for believing and the reasons for doubting. He states that it was the meta-narrative, the full picture of reality, that drew him to Christianity in the first place. The vision of a transcendent reality proved to be 'tantalisingly resistant to verbal expression' (p. 142). It is the recognition of ambiguity, or perhaps humility, that motivated McGrath's conviction that we are not asked to choose between a 'Christian faith and an atheist fact' (pp. 173-74) but between two opposite and equally unverified worldviews.

Although this book is intellectual in its concerns and aimed at more academically engaged Christians, it is not an academic book. This is one person's particular and unique view onto one of the most widely debated subjects of our time: the relationship between Christian faith and science. On top of that it is one man's engagement with and ultimate conversion to a transformational Christian faith. As such it invites all kinds of readers to sit back and benefit from the very reason for memoir; that the reader may look in on something very familiar from a different point of view. As someone who currently engages with Christian theism and science and reconverted to the Christian faith, I find these pages riddled with images of my own life. This book is unlikely to be revolutionary in the sense that there is not a ground-breaking argument or a newly-formed intricate theology, but it is a book that may be enjoyed much like one enjoys a good friend telling you a story you have heard many times before. There is comfort here. Perhaps some readers will recognize themselves in the strident young atheist. Perhaps they will even embrace the idea that they too may have dismissed the Christian enterprise too hastily. Ultimately this book is about faith. It is about acknowledging how much we do not know, accepting humility and choosing to believe.

Emma Mutch

Emma Mutch is completing doctoral research in the theology and philosophy of science (University of Glasgow) and animal genetics (University of Edinburgh).

https://doi.org/10.15664/tis.v28i2.2332

Theology in Scotland 